\title{
Game Edukasi Sebagai Media Pengenalan Lingkungan dan Pembelajaran TIK Bagi Siswa Kelas I Sekolah Dasar
}

\author{
Fransiskus Tjiptabudi \\ STIKOM Uyelindo Kupang \\ fransiskus_tjiptabudi@yahoo.com
}

\begin{abstract}
Abstrak
Semakin dini pengenalan lingkungan sekitar untuk anak-anak semakin baik. Hal tersebut sangat penting karena mampu menambah informasi dan pengetahuan dasar bagi anak-anak. Faktor didikan di rumah, pergaulan, dan berbagai faktor lain mempengaruhi tingkat pengetahuan anak tentang hal-hal yang ada di sekitarnya.

Edukasi merupakan sesuatu yang bersifat menyeluruh, yang memiliki makna lebih dalam daripada hanya sekedar belajar mengajar. Mendidik berarti membentuk karakter dan pola pikir seseorang. Maka dari itu, implementasi pendidikan tidak hanya mengacu pada mata pelajaran tertentu, tetapi juga mencakup semua hal yang bersifat informatif yang dibutuhkan oleh anak dimulai dari lingkungan sekitar seperti jenis tanaman, benda, buah, sayur, binatang, dan sebagainya.

Untuk menjawab permasalahan tersebut maka dibangun sebuah aplikasi komputer berupa game. Mengapa game? Karena game sendiri bersifat entertain atau mengibur. Hal ini tentu sesuai dengan psikologi manusia terutama anak-anak yang lebih suka bermain daripada belajar serius. Selain itu, penerapan game selain untuk menjadi media pengenalan lingkungan sekitar, juga menjadi media bagi anak dalam mengenal dan mempelajari teknologi informasi dan komunikasi (TIK). Dalam game, pendidikan diberikan lewat praktek atau pembelajaran lewat praktek (learning by doing).
\end{abstract}

Kata kunci : Game edukasi, media, TIK 


\section{PENDAHULUAN}

Saat ini, perkembangan teknologi informasi dan komunikasi (TIK) yang semakin pesat menjadikan peran komputer sebagai salah satu jenis teknologi semakin mendominasi berbagai bidang kehidupan manusia, termasuk bidang pendidikan. Seiring pesatnya perkembangan komputer, aplikasi-aplikasi komputer juga berkembang dengan pesat. Selain untuk membantu pekerjaan manusia, komputer juga menyediakan aplikasi yang menjadi media hiburan untuk mengisi waktu luang baik dilakukan bersama atau pribadi.

TIK sendiri mempunyai dua aspek, yaitu teknologi informasi dan teknologi komunikasi. Teknologi Informasi berkaitan dengan proses, penggunaan sebagai alat bantu, manipulasi, dan pengelolaan informasi, sedangkan teknologi komunikasi berkaitan dengan penggunaan alat bantu untuk memproses dan mentransfer data dari perangkat yang satu ke lainnya. Karena begitu berkembang dan pentingnya TIK bagi manusia, maka kebutuhan untuk mengenal dan mempelajari TIK menjadi suatu hal yang wajib. Tak heran bahwa TIK kini sudah diajarkan mulai dari tingkat pendidikan dasar.

Berbicara tentang pendidkan atau edukasi, tidak hanya berupa pelajaran ataupun sebatas diktat karena edukasi memiliki makna yang lebih dalam dari hanya sekedar belajar dan mengajar. Edukasi adalah sesuatu yang bersifat menyeluruh, sehingga dapat dikatakan bahwa edukasi berarti membentuk karakter dan pola pikir seseorang. Maka dari itu, sebenarnya implementasi pendidikan dalam aplikasi permainan komputer atau game tidak hanya mengacu pada pelajaran tertentu, tetapi harus mencakup semua tatanan pendidikan meski dengan spesifikasi tertentu misalnya tentang lingkungan di sekitar anak-anak.

Penggunaan game sebagai sarana pendidikan sebetulnya bukan hal yang salah karena game bersifat menghibur. Secara psikologi, manusia terutama anak-anak lebih suka bermain daripada belajar serius. Melalui game, pendidikan diberikan lewat praktek atau pembelajaran dengan praktek (learning by doing). Game secara tidak langsung mendidik anak melalui apa yang anak kerjakan atau lakukan dalam game tersebut dan apa yang dikerjakan dalam game tersebut secara tidak langsung akan mempengaruhi pola pikir dan perilaku anak. Hal inilah yang merupakan bagian dari edukasi.

Berdasarkan masalah yang ada dan mengingat bahwa Delphi merupakan salah satu software builder dengan menggunakan bahasa pemrograman tingkat tinggi dan mempunyai cakupan kemampuan yang luas dan sangat canggih [1], maka penelitian ini bertujuan untuk membangun sebuah game edukasi pengenalan lingkungan untuk siswa sekolah dasar dengan menggunakan Delphi 7.

\section{LANDASAN TEORI \\ 1. Game Edukasi}

Menurut Schell dalam [2], game dapat diartikan sebagai kegiatan penyelesaian masalah dan didekati dengan sikap yang menyenangkan, game juga sesuatu yang membuat pemain menemukan kesenangan dalam memainkannya.

Game edukasi merupakan game digital yang dirancang untuk pengayaan pendidikan (mendukung pengajaran dan pembelajaran), dengan menggunakan teknologi multimedia interaktif. Menurut Hurd dan Jenuings, perancang yang baik haruslah memenuhi kriteria dari education game itu sendiri [3]. Berikut ini adalah beberapa kriteria dari sebuah education game, yaitu:

a. Nilai Keseluruhan (Overall Value)

Nilai keseluruhan dari suatu game terpusat pada desain dan panjang durasi game. b. Dapat Digunakan (Usability)

Mudah digunakan dan diakses adalah hal penting bagi pembuat game.

c. Keakuratan (Accuracy)

Keakuratan diartikan sebagai bagaimana kesuksesan model/gambaran sebuah game dapat dituangkan ke dalam percobaan atau perancangannya.

d. Kesesuaian (Appropriateness)

Kesesuaian dapat diartikan bagaimana isi dan desain game dapat diadaptasikan terhadap keperluan user dengan baik.

e. Relevan (Relevance)

Relevan artinya game sesuai dengan user atau isi game dapat diaplikasikan ke target user. Agar dapat relevan terhadap user, sistem harus membimbing user dalam pencapaian tujuan pembelajaran.

\section{f. Objektifitas (Objectives)}

Objektifitas menentukan tujuan user dan kriteria dari kesuksesan atau kegagalan dari user dalam bermain.

\section{g. Umpan Balik (Feedback)}

Untuk membantu pemahaman user bahwa permainan atau performa user sesuai dengan objek game atau tidak, feedback harus disediakan.

\section{Media Pembelajaran}

Definisi media adalah sebagai alat untuk menyampaikan atau mengantarkan pesan-pesan. Sedangkan media pembelajaran meliputi alat yang secara fisik digunakan untuk menyampaikan isi materi pembelajaran, yang 
antara lain terdiri dari buku, tape recorder, kaset, film, gambar, dan lain-lain. Dengan kata lain media pembelajaran adalah komponen sumber belajar atau wahana fisik yang mengandung materi instruktusional di lingkungan siswa yang dapat merangsang siswa untuk belajar.

Adapun kriteria media berbasis komputer yang baik haruslah memenuhi persyaratan sebagai berikut [4]:

a. Kesesuaian dengan tujuan

Sesuai dengan kompetensi dasar dan indikator yang telah ditetapkan.

b. Kesesuaian dengan materi

Sesuai dengan materi, tidak ada kesalahan konsep dan mendukung pemahaman materi.

c. Efisiensi waktu

Pembuatan dan penggunaan media pembelajaran harus sesuai dengan waktu yang telah disediakan.

d. Mutu teknis

Mengarahkan kepada informasi atau pesan yang disampaikan dari media secara jelas dan berurutan, mengarah pada pemahaman konsep serta informasi itu dapat menumbuhkan kreativitas dan kemandirian siswa.

e. Kepraktisan dan keluwesan

Mudah untuk diperoleh, mudah dibuat sendiri oleh guru, dan dapat digunakan kapan saja, dan dimana saja.

\section{METODE}

Metode penelitian yang diterapkan pada penelitian ini adalah metode Research and Development. Menurut [5], penelitian dengan menggunakan metode Research and Development merupakan penelitian berbentuk siklus, diawali dengan adanya kebutuhan, permasalahan yang membutuhkan pemecahan dengan suatu produk tertentu. Langkah-langkah model pengembangan ini terdiri atas 4 tahap, yaitu tahap define (pendefinisian), design (perancangan), develop (pengembangan), dan disseminate (penyebaran). Namun, dalam penelitian ini tahap yang dilakukan hanya sampai pada tahap ketiga karena produk yang dikembangkan tidak sampai disebarkan.

a. Tahap pendefisian (Define)

Tahap pendefisian atau define merupakan tahapan untuk menetapkan syaratsyarat pembelajaran. Tahap awal ini berdasarkan pada berbagai macam kegiatan analisis, yakni analisis kebutuhan, analisis tujuan pembelajaran, analisis standar kompetensi dan kompetensi dasar, dan penentuan tujuan instruksional.
Kegiatan analisis pendefinisan dari produk ini digunakan sebagai acuan dalam membuat user interface dan fitur-fitur dalam game yang dikumpulkan melalui cara melakukan wawancara dengan responden.

b. Tahap perencanaan (Design)

Tujuan dari tahap ini adalah untuk merancang suatu perangkat pembelajaran. Tahap ini meliputi kegiatan penyusunan materi, pemilihan media, pemilihan format pengambangan media, dan desain awal. Pada tahapan desain awal meliputi langkah-langkah:

1. Menentukan materi.

2. Mengumpulkan bahan sesuai materi yang telah ditentukan.

3. Menentukan desain menu tampilan.

a) Perancangan form menu utama

Pada form ini terdapat menu yang didesain menggunakan komponen tombol yang bisa dipilih oleh user/siswa. Menu yang tersedia yaitu Mulai Permainan, Aturan Permainan, Daftar Nilai, dan Keluar.

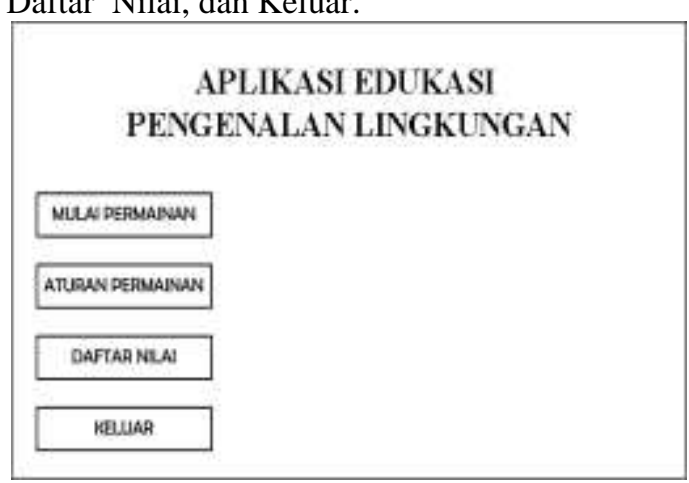

Gambar 1. Rancangan form menu

b) Perancangan form permainan

Pada form ini, soal akan ditampilkan pada komponen yang didesain menyerupai sebuah papan tulis. Disamping komponen tersebut terdapat sebuah komponen untuk menampilkan gambar jika soal yang ditampilkan dilengkapi dengan gambar.

Di bawah soal disediakan area untuk menampilkan jawaban. Terdapat urutan hurufhuruf yang menggunakan komponen tombol pada bagian bawah soal. User/siswa akan memilih huruf-huruf tersebut dengan cara menekan tombol dari huruf yang dipilih hingga membentuk jawaban yang sesuai.

Selain itu, terdapat sebuah tombol untuk menutup permainan jika permainan telah selesai dilakukan. 


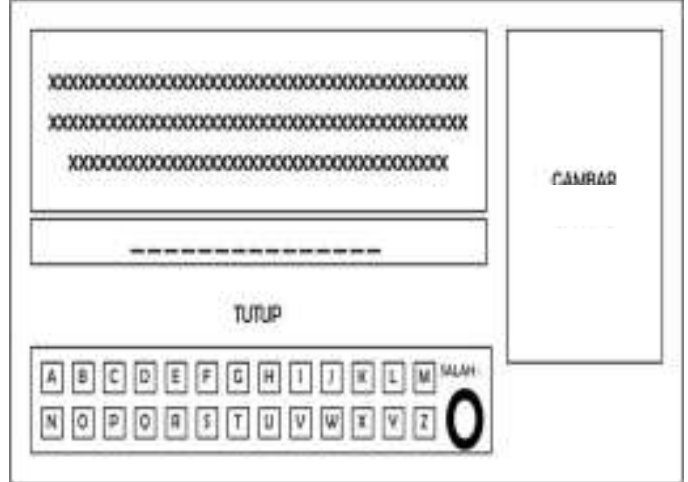

Gambar 2. Rancangan form permainan c. Perancangan form daftar nilai

Form ini akan ditampilkan saat permainan telah selesai atau form permainan ditutup. Form ini berfungsi untuk menginput nama user/siswa dan nilai yang diperoleh setelah selesai bermain dan menampilkan informasi tentang daftar user/siswa dan nilai yang diperolehnya.

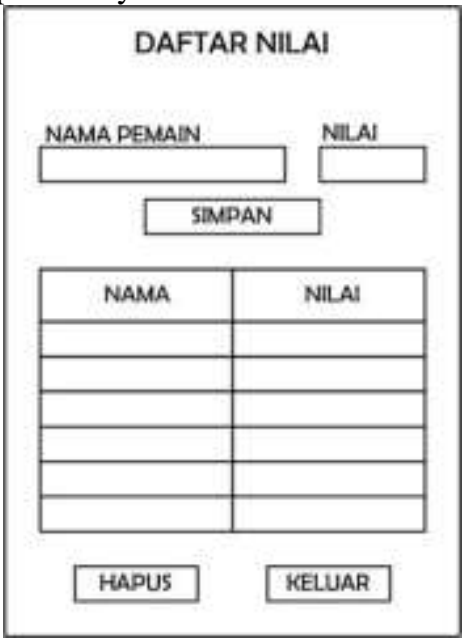

Gambar 3. Rancangan form daftar nilai

4. Penyusunan materi yang akan dimasukkan dalam tampilan awal.

5. Pembuatan media pembelajaran.

Sebelum dibuat, alur dari media pembelajaran harus didesain terlebih dahulu dalam bentuk sebuah flowchart. Flowchart program merupakan bagan alur yang menjelaskan secara rinci langkah-langkah proses dari sebuah program [6]. Flowchart game edukasi seperti pada gambar berikut:

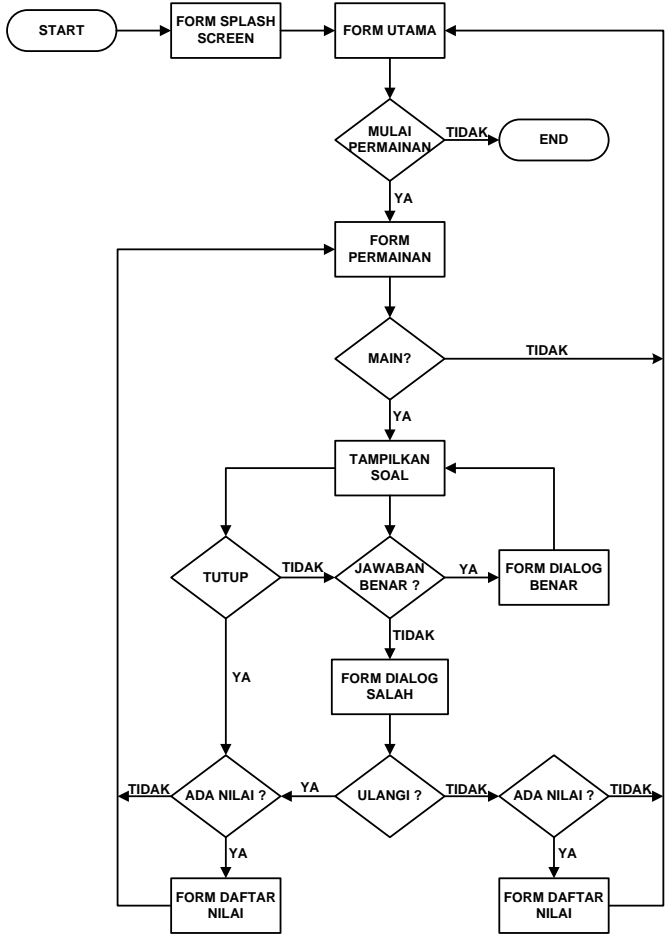

Gambar 4. Flowchart game

6. Mengemas media dalam softcopy.

c. Tahap pengembangan (Develop)

Tahap ini bertujuan untuk menghasilkan perangkat pembelajaran yang sudah direvisi berdasarkan masukan dari validator. Tahapan ini meliputi beberapa langkah, yaitu uji coba produk dan revisi.

Untuk melakukan uji coba produk, perlu dilakukan terlebih dahulu implementasi dari produk game tersebut.

1. Implementasi program

Implementasi atau penerapan program adalah proses dimana program yang baru dibuat kemudian dijalankan atau diujicoba. Tahap implementasi merupakan tahap meletakan program supaya siap untuk dioperasikan. Implementasi game ini harus memperhatikan spesifikasi kebutuhan perangkat keras (hardware) dan perangkat lunak (software). Dalam spesifikasi ini dijelaskan bahwa spesifikasi yang bagaimanakah yang paling tepat untuk menjalankan game ini agar dapat berjalan dengan normal yang tanpa masalah.

Game edukasi ini dapat dijalankan pada komputer yang menggunakan sistem operasi Windows, minimal Windows 7 dan memiliki sound dan grafis yang sudah terinstal. Game ini dapat diinstalasi pada komputer yang memiliki spesifikasi perangkat keras dengan kapasitas ruang penyimpanan yang dibutuhkan untuk instalasi sebesar $10 \mathrm{MB}$, menggunakan prosesor dual core atau lebih, memiliki memori utama (RAM) minimal 1GB, memiliki VGA card 
dengan memori minimal $512 \mathrm{MB}$ dan resolusi 1024 x 768 pixel.

Saat program dieksekusi, maka form menu game akan ditampilkan. Pada form tersebut terdapat empat (4) menu utama yaitu: menu Mulai Permainan, menu Aturan Permainan, menu Daftar Nilai, dan menu Keluar.

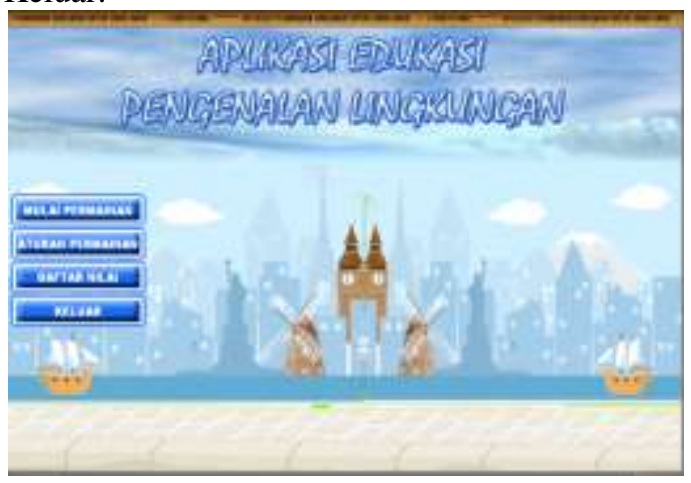

Gambar 5. Form menu game

Selanjutnya, game akan menampilkan soal pada komponen yang didesain menyerupai sebuah papan tulis hitam. Disamping papan soal terdapat sebuah komponen grafis untuk menampilkan gambar jika soal yang ditampilkan dilengkapi dengan gambar, sedangkan di bawah papan soal disediakan area untuk menampilkan jawaban berdasarkan huruf yang dipilih oleh user/siswa.

Terdapat urutan huruf-huruf yang menggunakan komponen tombol pada bagian bawah soal. User/siswa akan memilih hurufhuruf tersebut dengan cara menekan tombol dari huruf yang dipilih hingga membentuk jawaban yang sesuai.

Selain itu, terdapat informasi jumlah pilihan salah, informasi score dan sebuah tombol untuk menutup permainan jika permainan telah selesai dilakukan.

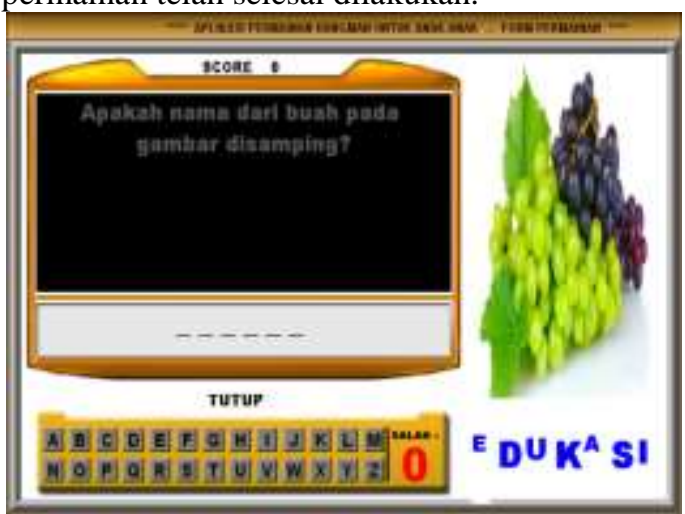

Gambar 6. Form permainan

Game juga menyediakan fasilitas daftar nilai. Form daftar nilai akan ditampilkan jika user/siswa memilih menu Daftar Nilai pada form menu atau pada saat menyelesaikan permainan. Dalam form ini, user/siswa dapat memasukkan nama sedangkan nilai sudah tersedia secara otomatis kemudian menyimpan data tersebut dan akan ditampilkan pada tabel nilai.

\section{Pengujian}

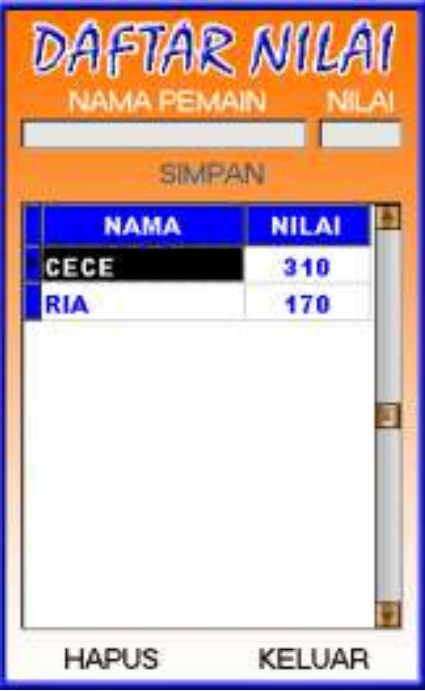

Gambar 7. Form daftar nilai

Proses pengujian game ini adalah dengan menggunakan metode black box testing yang berguna untuk menguji fungsionalitas suatu program. Parameter pengujian dengan menggunakan black box testing pada game ini dapat dilihat pada tabel berikut:

Tabel 1. Parameter pengujian

\begin{tabular}{|l|l|}
\hline \multicolumn{1}{|c|}{ Fungsi } & \multicolumn{1}{c|}{ Parameter } \\
\hline Tombol menu & Berfungsi dengan baik? \\
\hline Soal & Tampil dengan baik? \\
\hline Jawaban & $\begin{array}{l}\text { Sesuai dengan soal? } \\
\text { jawai dengan jumlah } \\
\text { Nilai }\end{array}$ \\
\hline
\end{tabular}

Hasil yang diperoleh dalam pengujian ini dapat dilihat pada tabel 2 .

Tabel 2. Hasil pengujian

\begin{tabular}{|l|c|}
\hline \multicolumn{1}{|c|}{ Fungsi } & $\begin{array}{c}\text { Hasil pengujian } \\
\text { parameter }\end{array}$ \\
\hline Tombol menu & $\sqrt{ }$ \\
\hline Soal & $\sqrt{ }$ \\
\hline Jawaban & $\sqrt{ }$ \\
\hline Nilai & $\sqrt{ }$ \\
\hline
\end{tabular}

\section{KESIMPULAN}

Berdasarkan hasil pengujian, semua fungsi dari game edukasi pengenalan lingkungan ini dapat berjalan dengan baik antara lain fungsi setiap tombol, fungsi menampilkan soal, kesesuaian jawaban dengan soal serta jumlah skor yang tepat.

Game ini dapat memberikan rangsangan yang baik bagi penggunanya karena untuk menjawab soal, user/siswa dituntut untuk tidak hanya sekedar menebak huruf yang akan dipilih, 
sehingga secara tidak langsung user/siswa dididik untuk berpikir kritis guna menjawab soal.

Selain itu, desain tampilan yang menarik, penggunaan suara dan efek animasi, penyajian soal secara teracak dapat memberikan nilai hiburan dan tantangan tersendiri kepada user/siswa dengan tidak melupakan nilai-nilai edukasi sehingga game edukasi ini dapat dijadikan sebagai sarana bermain sekaligus belajar.

\section{DAFTAR PUSTAKA}

[1] Kadir, Abdul, Pemrograman Dengan Delphi 7. Andi Publisher, Yogyakarta, 2005.

[2] Tjahyadi, M. P., Alicia S., Virginia T., \& Steven S., Prototipe Game Musik Bambu Menggunakan Engine Unity 3D, Universitas Sam Ratulangi. E-Journal Teknik Informatika, Vol. 4 No.2, Manado, 2014.

[3] Widiastuti, Nelly I., Irwan S., Membangun Game Edukasi Sejarah Walisongo, Jurnal Ilmiah KOMPUTA, Vol. 1, No. 2, Bandung, 2013.

[4] Arsyad, Azhar M.A., Media Pembelajaran, Raja Grafindo Persada, Jakarta, 2002.

[5] Juhanaini, Research and Development, Universitas Pendidikan Indonesia, Jakarta, 2012.

[6] Kristanto, Andri, Perancangan Sistem Informasi dan Aplikasinya, Gava Media, Yogyakarta, 2008. 
